\title{
Debating the Concept of Political Opportunities in Relation to the Galician Social Movement 'Nunca Máis'
}

\author{
SUSANA AGUILAR FERNÁNDEZ and \\ ANA BALLESTEROS PENA
}

During the anti-globalization march of 1 June 2003 through the French locality of Annemasse, site of the G-8 Summit, Spanish participants were to be seen waving banners displaying the slogan 'Nunca Máis' (Never Again). Although the majority of the demonstrators and onlookers were probably unaware of the meaning of the slogan, Nunca Máis embodied a new social movement which, having its origins in the catastrophic spill of the oil tanker Prestige off the coast of northeastern Spain, acquired an impressive socio-political relevance not only in Galicia, the region most affected by the ecological disaster, but in the rest of Spain, too.

More than six months before the Summit protest, on 13 November 2002, the single-hull tanker Prestige, loaded with 77,000 tons of petroleum, sent out an SOS message after suffering a major leak 28 miles from Fisterra on the Galician coast. Despite the adverse weather conditions, the government decided to pull the Prestige out to sea by means of tugboats. The route chosen was rather erratic and, in the end, proved fatal: at first the tanker was taken northwards, and then, following the alleged intervention of the French authorities in an effort to protect their own coastline, southwards, before finally steering eastwards. An oil slick first appeared on the Galician coast on 16 November. Three days later, the tanker broke in half, sinking to a depth of 4,000 metres 120 miles west of the Galician Cíes Islands while still holding around 50,000 tons of fuel. Over the following weeks, more and more oil invaded the Galician river systems known as the Lower and Upper Rias (Rias Bajas y Altas).

We would like to thank Roi Riberas, a member of Nunca Máis and a journalist with the Galician newspaper La Opinión, for having provided information. We would also like to express our gratitude to Dr Nigel Townson for revising the text. 
Although the spill has damaged the region of Galicia in particular, a total of nearly 3,000 kms of the Spanish coastline were affected.

Following the spill, and facing initial denial of the magnitude of the disaster by the Popular Party (PP) government, as well as its refusal of all sorts of material and human help, first at the regional level and then at the national one, fishermen and an increasing number of volunteers tried to limit the devastation with their own, patently inadequate tools. Accordingly, nets were cast from small fishing craft in a futile attempt to clear up the oil while volunteers set about cleaning beaches and cliffs with their bare hands.

On 27 November, the Nunca Máis Platform was set up in Galicia. Thereafter, the Platform played the leading role in the protest at the government's mismanagement of the crisis, drawing on both conventional and non-conventional interactions with its opponents while elaborating on innovative repertoires of collective action. Nunca Máis did not limit itself to denouncing the widely perceived tardy, secretive and self-deceiving approach of the authorities in relation to the Prestige calamity, but also gradually capitalized on widespread popular discontent regarding a number of important domestic issues. In essence, this was achieved by expanding the movement's original agenda to embrace citizens' demonstrations against the war on Iraq and criticism of the supportive role played by the PP government in relation to the Bush administration. This strategy converted Nunca Máis into part of a broader protest movement which brought hundreds of thousands of disenchanted citizens onto the streets.

CHALLENGING THE POLITICAL PROCESS APPROACH: ALTERNATIVE EXPLANATIONS FOR THE EMERGENCE, AND THE CONSEQUENCES, OF NUNCA MÁIS

Beyond the tremendous ecological damage and the disastrous economic consequences of the spill for the fishing sector, the social response to the Prestige was probably sharpened by a succession of similar accidents over the previous decades: Polycommander (1970), Urquiola (1976), Andros Patria (1979), Casón (1988) and Mar Egeo (1992). Bearing in mind the recurrence of spillages, the first question we address is the following: why does Nunca Máis emerge in the year 2002 and not before? The question is not without its logic because the nature of, and the reasons for, the above mentioned accidents were similar, even if the consequences were not as damaging as those of the Prestige. All these cases involved the spill of oil, or hazardous chemical substances, which profoundly deteriorated the ecological quality of the sea and impinged harmfully upon the fishing 
activity of the region. Moreover, all were largely brought about by low maritime security standards and an inadequate policy in relation to an area characterized by an enormously dense sea traffic.

The question of the 'when' is the key one for Sidney Tarrow (1998), one of the leading theorists on social movements. This is because it offers the chance to analyze the political context (or the political opportunity structure) as the variable which accounts for the timing of the protest. According to the political process approach adopted by Tarrow, amongst others (such as Tilly 1978, McAdam 1985, Kriesi 1992 and Kitschelt 1996), political shifts and changes can take place which, while not being caused by the protestors, can open up new opportunities for such movements. Since this approach 'perceives movements as primarily political, making demands of the state and asking for changes in laws and policies, they see changes in the state as the most important opportunity a movement needs' (Goodwin and Jasper, 2003: 12).

In contrast to this approach, we contend that, rather than the political opportunity structure per se, unexpected changes in the non-political context - adopting the form of collective moral outrage and unforeseen grievances - and the existence of social networks that can, if necessary, be quickly activated, are the most important variables in relation to the timing and impressive mobilizing capacity of Nunca Máis.

The second question to be addressed refers to the impact of Nunca Máis. The literature regarding social movements has invariably overlooked this crucial aspect. In discussing cycles of protest, Tarrow (1998: 24-25) identifies just three different scenarios: repression, and the subsequent dissolution or weakening of the social movement; revolution, which results in a profound transformation of the status quo and the complete realization of the social movement's aims (although examples are extremely hard to come by); and negotiations, which lead to the institutionalization or taming of the social movement. We find this analysis unsatisfactory, not only because it oversimplifies the variety of outcomes that may result from the interaction between social movements and authorities, but also because it erroneously embraces a zero-sum game: while revolution signifies a total gain for the social movement, repression signals a total loss.

The middle way - negotiation - is implicitly downgraded as it is regarded as a sell-out on account of the alleged co-optation of the leadership and the perceived integration of the protesters into conventional politics. None the less, we maintain that the political game within a democracy is best represented by the middle way: the changing interactions between different actors allow a social movement either to advance or to retreat. This cannot be represented as a Manichean take-all 
or lose-all game. On the contrary, we define success as the gradual advancement of a social movement's objectives, this being brought about when contenders, drawing on social networks and resources that facilitate collective action, either encounter responsive authorities or else force the authorities to respond. In order to succeed, it is crucial that a social movement frame its demands in such a way as to generate common identities, and shared definitions of the situation, at the rank-and-file protestor level.

Thus, the magnitude of the (environmental) moral outrage and the immediate social response to it misled the organizers of Nunca Máis into thinking that the movement was united and cohesive. This led in turn to a neglect of the framing processes, or of what McAdam has defined as the 'cognitive liberation dimension' (1985). This is the fundamental reason why Nunca Máis failed to bring about specific policy, as well as broad political, changes, both at the regional and national levels. It is also why Nunca Máis miscalculated the effects of the divisive compensation policy undertaken by the government. Precisely because the political process approach attaches disproportionate importance to the macro and exogenous variables of the opportunities proffered, as well as the restrictions imposed, by the state, cognitive framing is not sufficiently considered.

Before entering into this discussion, however, we will first explain why we consider Nunca Máis a social movement, as opposed to a radical political organization led by a cabal of professional agitators (as some opponents claimed), and analyze the factors that account for its mobilizing power. Second, we will describe the political context in which the movement found itself, and analyze why this was unfavourable in terms of Nunca Máis' aims. Finally, we assess the reasons why the movement failed to provoke substantial policy and political change.

\section{THE DEVELOPMENT OF NUNCA MÁIS: THE RELEVANCE OF EXISTING SOCIAL NETWORKS}

A social movement, according to Tarrow, can be defined as 'those sequences of contentious politics that are based on underlying social networks and resonant collective action frames, and which develop the capacity to maintain sustained challenges against powerful opponents'. More specifically, he maintains that 'contentious politics occurs when ordinary people, often in league with more influential citizens, join forces in confrontations with elites, authorities, and opponents' (1998: 2).

Following this definition, Nunca Máis clearly represented a serious challenge to 'business as usual' within Galician politics, partly because it 
drew attention to the political shortcomings relating to the management of the Prestige disaster and partly because it brought into question the maritime security policy of the regional government. All this was linked to the public authorities' lack of response at the beginning of the crisis and to their attempts, at a later stage, to control, repress and even demonize the Nunca Máis movement. ${ }^{1}$ By stressing the non-responsive and nonnegotiable (if not 'authoritarian') stance of the government, Nunca Máis managed to project this perception of the PP from the regional to the national level at a moment in which the government was facing increasing opposition to Spanish involvement in the Iraq war. This challenge was clearly facilitated by the existence of social networks which, in alliance with other actors, helped Nunca Máis sustain a confrontation with basically political antagonists. One could even argue that Nunca Máis represents a case of 'bloc recruitment', in the sense that the organizers succeeded in integrating entire social networks into the movement (Oberschall in Goodwin and Jaspers, 2003).

Although the political parties opposed to the PP, above all the BNG (Galician Nationalist Bloc), undoubtedly took the lead in creating Nunca Máis, the movement soon acquired a momentum of its own which defied that of any single actor or group. In this sense, social movements embody 'continuously negotiated interactions among persons and sets of persons' and 'any particular person often plays parts within more than one political actor' (McAdam, Tarrow and Tilly, 2002: p.12). In the case of Nunca Máis, people displayed cross-cutting as well as overlapping affiliations, constantly differing constellations of associations being the rule.

Indeed, it is always difficult to assign protagonism within a particular social movement to specific individuals or groups. Even if a movement is brought into being by identifiable actors, the continuously changing relations with other, pre-established, social groups or networks lead to shifting alliances, sometimes resulting in uneasy strategic coalitions. The leadership of Nunca Máis belonged above all to the world of arts and culture, not to politics, which is why the movement was always much more than a mere political coalition of anti-PP parties. Although Table 1 does not include all the associations that participated in Nunca Máis, it does contain the biggest ones as well as revealing that the bulk of its membership (259 associations out of 285) belonged to what could be called 'non-politically affiliated civil society'. These associations cannot be regarded as mutually independent since overlapping membership tends to be the rule.

The 'early risers' in the formation of Nunca Máis were the left-wing nationalists (the BNG and the CIG union, the Galician Confederation of Unions), which, shortly after the sinking of the Prestige, met in order to 
TABLE 1

NUNCA MÁIS' MEMBERS

\begin{tabular}{lc}
\hline Type of association & Number of individual associations \\
\hline & \\
Economic-productive associations (mainly fishermen) & 55 \\
Cultural associations & 55 \\
Students, youth and teachers' associations & 41 \\
Neighbours' associations & 29 \\
Ecological and environmental associations & 23 \\
Professional associations (lawyers, historians...) & 20 \\
Leisure and sports associations & 22 \\
Housewives' and women's associations & 14 \\
Unions & 11 \\
Political parties & 8 \\
Friends of the Republic and anarchist-oriented groups & 7 \\
TOTAL & 285 \\
\hline
\end{tabular}

Adapted from www.plataformanuncamais.org (15 November 2003)

analyze the ecological catastrophe. At this meeting, it was agreed that the unions, the fishermens' organizations (the cofradias), and the environmental, student and other like-minded groups should join forces. Once minor discrepancies amongst the leading organizations were resolved, the movement's name - 'Nunca Máis' - and its programme - which included the demand that the key political figures implicated in the disaster should resign - were agreed upon. The first demonstration, which saw over 150,000 people march through the Galician capital of Santiago on 1 December 2002, represented a watershed in the history of collective action in the region. Still, the biggest demonstration of all occurred in Madrid on 23 February 2003: over one million people took to the streets in order to protest against the war on Iraq, Nunca Máis joining in as a privileged participant.

The Galician Socialists (the PSG-PSOE) and the national trade unions (the UGT and CC.OO.) supported the demonstration in Santiago while initially refusing to join Nunca Máis itself on account of the protagonism of the BNG. However, such misgivings receded once it became clear that Nunca Máis embraced a much broader socio-political spectrum than that represented by Galicia's left-wing nationalists. In fact, the movement has functioned as a relational mechanism - in accordance with the definition of McAdam, Tarrow and Tilly (2002) - in the sense that it has brought together disparate elements through a common indignation at the political neglect shown in relation to the spillage. Some of these elements, moreover, seized on the opportunity provided by the Prestige disaster to manifest a deep-seated, long-standing discontent with the PP at both a regional and national level. Intellectuals and artists, who shortly after 
the spillage created the Plataforma contra la Burla Negra (The Platform against Black Mockery), joined Nunca Máis at its outset and became the visible, public face of the movement.

\section{Innovative Repertoires and the World of Arts and Culture}

The involvement of many figures from the world of culture and the arts accounts in large measure for the innovative repertoire of Nunca Máis. The most salient examples of this innovatory dimension were the organization of a 'Bagpipe Tide' (Marea Gaiteira) in Santiago, with the attendance of around 20,000 people; an exhibition, called 'SOS in a Bottle' (Botella al Mar), which took place in a tent made out of white outfits used by the volunteers who helped to clean the beaches and cliffs; the protest event of 'The March of the Suitcases' (Marcha de las Maletas) in La Coruña, when 100,000 people represented the drama of Galician emigration; the human chain of 60,000 children surrounding the Roman Wall in Lugo; a five minute black-out to denounce the authorities' blindness (this protest was supported by over 200 websites throughout Spain); a symbolic 'Wake of the Sea' (Velatorio del Mar) at Orzán beach in La Coruña; a festive demonstration headed by the Three Kings of the Spillage (Reyes Magos del Chapapote); and the distribution at a demonstration of a rubber dragon and a pack of cards that, by imitating those handed out by USA army officers in the Iraq war, exhibited the faces of those politicians responsible for the Prestige disaster. All this has been complemented by Black Humour sessions, solidarity concerts, handholding demonstrations, so-called 'expansive' music events, casserolebangings, critical photographic and cartoon exhibitions, marathons and a bike protest à la Tour de France, amongst other activities.

\section{The Neglect of Cognitive Frameworks}

Alongside such repertoires, one of the main tasks of a social movement is to create a set of symbols that are sufficiently recognizable and attractive in order to mobilize public opinion. The attack on the sea - a symbol of Galician identity - was first identified by activists of Nunca Máis as an idea around which people from very different walks of life could rally. This attack was interpreted by many as a devastating blow to the future of younger generations and to the prospects of a region long afflicted by poverty and emigration. At a later stage, this idea was integrated into a broader cognitive framework by which the identification of the injustice (the absence of preventive measures to avoid maritime disasters such as that of the Prestige

and the poor political response to the spillage), the attribution of responsibilities (to the Galician and Spanish governments along with the insurance companies, the tanker's owners, etc), and the search for solutions 
(economic compensation, political resignations and the putting into practice of a reliable maritime security policy) could be achieved.

However, the magnitude of the popular response was such that the Nunca Máis organizers initially overlooked the importance of a consciousness-raising campaign based on the creation of unifying motifs and slogans, in addition to the elaboration of an appealing programme. In this regard, the disaster of the Prestige constituted a 'suddenly imposed grievance', in the sense that it was an unexpected and dramatic event that highlighted numerous social problems. It could also be considered a moral shock, this occurring when 'events or information raise such a sense of outrage in people that they become inclined towards political action, with or without a network of contacts' (Walsh in Goodwin and Jaspers, 2003: 52, 54).

The far-reaching environmental and economic impact of the Prestige disaster can be examined in the light of the three types of framing postulated by Snow and Benford. These are: the diagnostic (when a movement convinces potential allies of the need to tackle a problem), the prognostic (when a movement builds on strategies, tactics and targets), and the motivational (when a movement exhorts individuals to become involved) (ibid: 52). During its early stages, Nunca Máis was largely representative of the second, or prognostic, type of framing, while having little to do with the other two. Accordingly, the initial agenda of the movement was rooted in four principal demands:

(1) the identification of responsibilities, both political and judicial;

(2) the swift adoption of economic palliatives, such as due compensation for all those affected;

(3) the application of ecological measures that, by going beyond the most 'politically-visible' ones of cleaning beaches and cliffs, stimulated the regeneration of the entire maritime environment, as well as the extraction of the remaining fuel within the tanker;

(4) the reform of current governmental policy so that maritime security standards were increased and coordinated, preventive practices adopted. With this aim in mind, the EU was also approached: Nunca Máis members travelled to Brussels and asked for the European Parliament to open an inquiry into the Prestige disaster.

\section{DID GALICIA PRESENT A FAVOURABLE POLITICAL CONTEXT?}

As a result of the Constitution of 1978, which introduced a quasi-federal territorial system, each of the 17 autonomous regions, or comunidades autónomas, that make up Spain passed their own statutes of autonomy. 
TABLE 2

ELECTORAL RESULTS IN GALICIA

\begin{tabular}{lrrrrrr}
\hline & 1981 & 1985 & 1989 & 1993 & 1997 & 2001 \\
\hline AP/PP & & & & & & \\
PSG-PSOE & 26 & 34 & 38 & 43 & 42 & 41 \\
BNG & 16 & 22 & 28 & 19 & 13 & 17 \\
UCD & 3 & 1 & 5 & 13 & 18 & 17 \\
EG & 24 & & & & & \\
PCG & 1 & & & & & \\
PSG-EG & 1 & 3 & 2 & & & \\
CG & & 11 & 2 & & & \\
EU-EG/ Os Verdes & 71 seats & 71 seats & 75 seats & 75 seats & 75 seats & 75 seats \\
TOTAL & & & & & & \\
\hline
\end{tabular}

Notes:

1. List of acronyms: AP/PP (Popular Party, conservative party), PSG-PSOE (Galician Socialist Party-Spanish Socialist Workers Party, the Galician branch of the Socialist Party,), BNG (Galician Nationalist Bloc, left nationalists), UCD (Democratic Centrist Alliance, centrist-conservative party under the leadership of the first democratic President of Government after the 1977 elections, Adolfo Suárez, which entered mounting crisis after the poor 1979 results), EG (Galician Left), PCG (Galician Communist Party), PSG-EG (Galician Socialist Party-Galician Left), CG (Galician Coalition), EU-EG/Os Verdes (Galician Left/ The Greens). Further information about regional Galician elections can be found in http://www.lavozdegalicia.es/especiales/elecciones_gallegas/index.jsp.

2. This formation ran for election in coalition with the PSG-PSOE.

Since 1980, the year in which the Galician Statute of Autonomy was approved, six regional elections have taken place in this north-western region. In all six elections, the PP has been first past the post, though for the first two mandates (those of 1981 and 1985), agreements had to be struck with other political forces in order for the PP to rule the region. The only setback to the PP's hegemony was the ousting in 1987 of Fernández Albor from the Presidency of the Regional Government (the Xunta) in favour of the socialist, González Laxe. This came about as a result of a no-confidence motion backed not only by the socialists (PSGPSOE), but also by former members of the PP. The principal reason for this unholy alliance was that erstwhile PP member, José Luis Barreiro, who had once been regional vice-president under the PP, regained this position as a result of the agreement with the PSG-PSOE.

If the results from the six elections are compared, three trends stand out:

(1) the steady rise in electoral support for the PP, above all since the 1989 elections (the first in which Manuel Fraga Iribarne, ${ }^{2}$ a former Francoist minister, ran as president for the Xunta), which mark the beginning of majority conservative rule; 
(2) second, the growing simplification of the political landscape: the number of political formations in the regional parliament has decreased over time, there being just three at present (the PP, the PSG-PSOE and the BNG);

(3) finally, the growing convergence in electoral terms between the PSGPSOE and the BNG, this resulting in a draw between them in the 2001 elections. Socialist losses, especially since the 1993 elections, have mainly been to the benefit of the left-wing nationalists. The latter's advance can be explained in terms of their more moderate policies since 1989, a notable organizational and activist capacity, and the strength of the leadership centred on José Beiras (Maíz and Losada, 2000).

Consequently the PP has been the governing force in Galicia for 23 years, for 15 of which Manuel Fraga has been the regional president, his leadership having never been questioned either by his party or by the Galician electorate. The reasons for his long-standing tenure in office are complex and cannot be dealt with in detail here. In brief, Fraga, with his Galician origin and his close control of the party apparatus, has capitalized both on Galicia's peculiar socio-economic structure (characterized by its backwardness, its rural base, and its geographic isolation, all of which are aggravated by poor communication networks) and its idiosyncratic political culture (in which clientelism, together with the conservatism of the peasantry, remains prominent) to establish a political domination which is based on the administration of selective benefits in exchange for electoral support. The fact that Galicia is a leading PP stronghold demonstrates that this strategy has been highly successful. ${ }^{3}$

Rural Galicia is clearly at odds with important sectors of the urban, secular and middle-class population, whose support for the left is very apparent (as shown by the case of the city of La Coruña, which has had a Socialist mayor, Francisco Vázquez, for 21 years). These social sectors, alongside the opposition parties and certain trades unions, have looked on with impotence and frustration as Fraga's leadership and clientelistic politics have won election after election, and might well have perceived the Prestige spill as an opportunity to gain some political advantage. Thus, the emergence of Nunca Máis cannot simply be explained by the existence of an objectively favourable political opportunity structure, as Galician politics was fairly stable when the movement was created. Yet before questioning the relevance of the concept of political opportunity to this specific case, some attention should be devoted to the way in which this variable is defined by the political process approach 
and to the specific way in which it relates to Galician politics at the time of the disaster.

Towards a Definition of Political Opportunity: The Difference Between Windows and Horizons of Opportunity

Tarrow (1989: 77-78) defines political opportunity as 'consistent - but not necessarily formal or permanent - dimensions of the political environment that provide incentives for collective action by affecting people's expectations for success or failure'. In a similar fashion, Kriesi (1992: 116-17) conceives of the political opportunity structure as 'those aspects of the political system that determine the development of the social movement, independently of the deliberate action of the actors in question'. Both definitions stress the importance of external resources to the social movement insofar as new political incentives can appear that, by affecting expectations of success or failure, condition people's willingness to participate in collective action.

Another important element in the concept is that most opportunities are situational, and not structural (Tarrow, 1989). That is to say, changes in the political environment do not necessarily have to affect the historically-rooted and well-entrenched features of the polity, but may simply alter contextual elements in the short run, such as electoral alliances or the issue-attention cycle. In accordance with Tarrow, the key dimensions of (situational) political opportunities are:

(1) increased access to participation for new actors, which is manifested most clearly in elections during periods of transition to democracy, as the electoral process has not yet become a routine that generally eschews contention within the democratic system;

(2) the evidence of political realignment and electoral instability within the polity;

(3) the appearance of influential allies, or actors sympathetic to the protestors, occupying key positions in the state apparatus;

(4) emerging splits and conflicts within, and between, the elites;

(5) a decline in the state's capacity, or will, to repress dissent.

A principal shortcoming of these dimensions is that they are more readily adapted to non-democratic political contexts, or uncertain ones, such as transitions to democracy, than to democratic ones. Indeed, Tarrow discusses them in relation to the liberalization measures introduced by Gorbachev in the former Soviet Union. Under democratic regimes, these dimensions do not necessarily have to be conceived of as political opportunities because, being part of the dynamics of everyday 
politics (or the rules of the game), they are not conducive to enhancing the chances of success of a protest.

Further, when the Prestige spillage took place, none of these dimensions were present in the Galician political context. Not only was the next election relatively distant in time (the accident occurred in November 2002 and local elections were due in May 2003), but also no evidence of shifting alliances or crises within the polity was such as to facilitate the challengers' mobilization. ${ }^{4}$ The only political resource at the disposal of Nunca Máis was the existence of allies within the polity, basically the opposition parties, the BNG and the PSG-PSOE. Still, these allies were not strong enough to create important opportunities, as the failure to set up a regional parliamentary enquiry into the disaster in the face of the PP's opposition demonstrated. Yet this resource is qualitatively different from the (sudden) appearance of new high-profile political actors who, under uncertain conditions, are ready to undertake personal risks in order to respond to the claims of new social movements, as Tarrow's discussion of the case of the Soviet Union seems to imply.

Although opportunities are basically situational, there are also more stable (or structural) dimensions to them:

(1) the state's strength, which is understood in a two-fold way: centralization vs decentralization (decentralized states, by providing a greater number of points of access to challengers, tend to diffuse the protest, while centralized ones attract protestors to the core of the polity and are likely to provoke important political convulsions) and high vs low enforcement capacity (strong and responsive 'enforcers' can facilitate the application of the policies demanded by a social movement, or hinder them if they are not responsive, while weak 'enforcers', even if willing to respond, may not be able to implement the changes called for by the challengers); ${ }^{5}$

(2) the state's prevailing strategies towards challengers, which can be fundamentally inclusive and facilitatory (revealing a high responsiveness to claims and demands), or exclusive and non-facilitatory

(3) the state's modes of repression and social control (Tarrow, 1989: 81$){ }^{6}$

Drawing on these three dimensions, the political opportunity structure which Nunca Máis encountered can be characterized, on the one hand, by the existence of a decentralized state. This type of state, according to Kriesi (1992: 120), opens up new opportunities to social movements: 'the degree of formal access to the state is a function of its degree of 
(territorial) centralization. The bigger the decentralization, the bigger the formal access. Decentralization implies multiple points of access'. Due to Spain's membership of the European Union, a multi-level game was also 'available' to the social movement, this undoubtedly enhancing its chances of success, as a study concerning the consequences of the principle of subsidiarity on environmental policy has recently shown (Aguilar, Font and Subirats, 1999).

On the other hand, the state was also characterized by an exclusive, non-responsive and non-facilitatory strategy (lacking the willingness to address the challengers' demands) which tried, in different ways, to control and repress the movement. Although we will deal with these aspects at a later stage, it is necessary to stress here that, with the exception of the element of decentralization (which eased the broadening of the original stake of Nunca Máis by means of transcending the initially locally-based protest), the political context that the structural dimensions of the concept of political opportunity delineate was far from favourable.

In relation to the analysis presented so far, two basic elements of the concept of political opportunity should be highlighted:

(1) favourable opportunities have a strictly political character and can affect the polity in a broad sense: the executive and the government, the electoral alliances of the political incumbents, the administration and the civil servants, the judicial system and even the parties and the unions;

(2) the opportunities can be situational and shifting or, though this is less likely, structural and stable.

The first element is not of much interest for our case. Because opportunities are defined in such a broad, political fashion, no other element of the situation which is not strictly political is envisaged as conducive to increasing people's disposition to undertake collective action. However, the second element of the concept does add a useful time perspective to our analysis, as situational opportunities, as opposed to stable ones, are invariably easier to seize by protestors in the short and medium term, as the members of Nunca Máis soon discovered. Thus Goodwin and Jaspers (2003: 257) stress that opportunities can be understood in terms of the short term: 'The media suddenly notice your cause, perhaps because of a crisis or accident (...) You must move quickly to use them to get your message across'. By contrast, access to structural opportunities requires the marshalling of greater resources (ranging from the economic, organizational, and cultural to the ideological) as well as a longer time frame. 
Drawing on the differences between structural and situational opportunities, Goodwin and Jaspers distinguish between horizons of opportunity, or the permanent features of a country's political landscape (constitutions, electoral laws, legal systems and the like), which constrain a social movement as well as define what is, and is not, possible, and windows of opportunity, which must be seized quickly as they can open and shut in no time (ibid: 258). The horizon of opportunity coincides with what Tarrow and others understand as structural political opportunities, whereas the window of opportunity would define a situational political opportunity.

Clearly, the Prestige disaster opened a window, and not a horizon, of opportunity, as we will show when discussing the reasons why Nunca Máis - contrary to expectations - failed to notably damage the PP in Galicia's local elections of May 2003. As a result, our criticism is basically directed at the reductionist political nature of the concept of opportunity, as defined by mainstream theorists. This concept does not sufficiently explain the 'when' because nothing in the Galician political opportunity context seemed to change, or to be changing, at the time of Nunca Máis' appearance in order to offer new incentives for collective action. Further, if we go beyond the analysis of the context which existed prior to the beginning of contentious action (which we will label the pre-political opportunity structure, or pre-POS), and tackle the type of political scenario which emerged after the social movement had come of age, and which was evolving in the (confrontational) interaction between the regional government and Nunca Máis (the post-political opportunity structure, or post-POS), a non-facilitatory environment is evident once again.

The political process approach, following Tilly's seminal book, From Mobilization to Revolution (1978), generally accepts that a political context ranges from 'repression' (when the individual costs associated with collective action are far-reaching as authoritarian, non-democratic regimes may repress social movements through violent, illegal measures in order to ensure their political survival) to 'facilitation' (whereby the individual costs in liberal democratic regimes are far less), with 'toleration' lying between the two. Yet it should be stressed that, under democracy, the reaction of the authorities to the challenge of social movements is enormously heterogeneous.

In our case, the pre-POS was rather static, exhibiting no visible changes which might have offered new incentives for collective action. Similarly, the post-POS encountered by Nunca Máis was far from facilitatory either. ${ }^{7}$ Contentious actions organized by Nunca Máis (such as sit-ins and demonstrations against individual politicians) mostly ended 
up in confrontations with the police, resulting in arrests and imprisonment. This was not surprising, insofar as most democratic regimes tend to react with great assertiveness, if not aggression, to actions which disrupt established social and economic activities. However, the regional government's response - what de la Porta and Rieter (1997) have defined as the 'policing protest' - was clearly disproportionate (understood as the adequacy, in both quantitative and qualitative terms, of the means used in relation to the attainment of the specific goals).

More significantly, conventional collective action undertaken by Nunca Máis also faced similar obstacles. Numerous initiatives were adopted in order to impair Nunca Máis' non-contentious activities. Perhaps the most flagrant was the letter sent by the regional Director General of Education, Alberto González, on 12 March 2003 to all state schools. In this, he urged the schools not to permit the display of Nunca Máis material on the grounds that 'the use of these spaces for propaganda, publicity or non-educationally-related questions [was] clearly illegal'. Consequently, the contention of Baker et al. (1997: $22-23)$ that:

the failure of the state adequately to address the problem of environmentally damaging activities affecting public welfare, (...) that often generates opposition at the grassroots level, [and that translates itself] in legitimating concerns of the polity that can act as political opportunity structures for grassroots activists to pressure the state and gain concessions...

does not apply to the Nunca Máis case.

\section{GOING BEYOND THE CONCEPT OF POLITICAL OPPORTUNITY TO EXPLAIN THE EMERGENCE OF NUNCA MÁIS}

If the concept of political opportunity does not prove a sufficient explanatory variable, the question as to why Nunca Máis was set up in November 2002 and not before, given that the Prestige disaster was not the first accident of this type and that the existence of political opportunities at the time was far from apparent, remains unresolved. The solution may lie in adopting a broader, and more complex, vision of a facilitatory context. Certainly this approach has been adopted by a number of authors who otherwise subscribe to the political process approach: 'the issue of emergence focuses attention on the various contextual conditions that nurture the soil for social movements and thus facilitate their development', political opportunity being only one of the elements, together with conditions of strain (such as demographic change or ethnic competition) 
and facilitative organizational contexts, amongst others, that are conducive to mobilization (McAdam and Snow, 1997: 15, our italics). In the case of Nunca Máis, the incorporation of two factors, neither of which belongs strictly to the concept of political opportunities, might shed some light on the timing of the social movement.

First, the oil spillage might have been perceived, rightly or wrongly, by many ordinary people as a window of opportunity by which they could express their discontent with the long-standing rule of the PP in the region. Most prominently, the political opposition to the PP also seized upon the chance offered by the disaster of the Prestige to advance their cause. Still, the political opportunity structure was, objectively speaking (as argued above), not at all favourable. None the less, as Koopmans has convincingly demonstrated, the way in which the political conditions of a particular country enter the strategic calculations of the challengers depends on the type of movement (in Kriesi, 1992). In other words, for a social movement the political context is not an objective, given element because challengers interpret, define, and can even invent it. Social movements sometimes fail calamitously precisely because the imagined construction' of the political situation supersedes reality.

This is what happened to Nunca Máis when, at a later stage of the campaign, it attempted to convert the window of opportunity into a horizon of opportunity. This was undertaken because widespread concerns about the PP at the national level - including the war in Iraq, trade union protests about labour market reform, and high-profile financial scandals such as 'Gescartera' - were interpreted as creating a context that was sufficiently favourable to allow Nunca Máis to broaden support for its critique of the PP at the Galician regional level. The strategy did not succeed, although collective action at both the regional and the national levels, along with the forging of linkages between the new actor, Nunca Máis, and established ones that were antagonistic to the PP, helped the movement to transcend its locally-based protests and extend its claims. Moreover, both elements assisted Nunca Máis in reducing the high transactional costs of collective action which derived from a non-facilitatory political structure.

Second, the magnitude of the ecological catastrophe of the Prestige cannot be compared to previous disasters, whose damage was much more limited in space and time. In this respect, the recent recognition by mainstream theorists that environmental mechanisms can strongly condition people's willingness to undertake collective action independently of the existence or otherwise of political opportunities represents an important contribution to the understanding of social movements whose emergence has not been directly affected by changes in 
the political context. Environmental mechanisms, understood as 'externally generated influences on conditions affecting social life (...), (such as) resource depletion or enhancement, [that] affects people's capacity to engage in contentious politics' (McCarthy and Zald in McAdam, Tarrow and Tilly, 2001: 25), have been recently incorporated into a wide-ranging theory which endeavours to account for many different types of contention.

The notoriously harmful ecological effects of the Prestige's spillage went hand in hand with the extensive damage inflicted upon the Galician economy, its fishing fleet - which represents half of Spain's - being one of the most important in the European Union. Indeed, the fishing sector is crucial to the economy of the three Galician provinces (La Coruña, Lugo, Pontevedra), out of a total of four, which give onto either the Atlantic Ocean or the Cantabrian Sea. Overall, the fishing sector contributes 10 per cent of regional GDP. Admittedly, the proportion of the active population employed by the fishing sector only amounts to 4.5 per cent (or 41,600 people), but once all the fishing-related activities, including commercialization and the canning industry, are taken into account the total number of jobs involved rises to 119,874. Not surprisingly, the areas most affected by fishing activity are the coastal ones. In Fisterra, for example, 47.2 per cent of the active population works in the fishing sector, while in Ribeira the figure stands at 39.9 per cent and in Cariño 36.9 per cent, Malpica 32.4 per cent, and Cangas 31.9 per cent, to name just a few.

In sum, we contend that the Prestige was initially perceived as a window of opportunity in order to introduce changes into a static regional political scenario, but that it was later regarded as a horizon of opportunity in order to contest certain aspects of the PP's rule at the national level. For their part, the Galician authorities displayed little inclination to put integrative strategies towards the challengers into practice, but this did not impair the continuation of the collective action. It may well be that a satiation effect shaped the perception by many non-PP voters that the spillage was an opportunity to modify the political situation in Galicia by non-electoral means. Equally relevant is the fact that the national political context was interpreted as sufficiently favourable in order to broaden the protest by extending criticism of the $\mathrm{PP}$ at the regional to the national level. By enlarging the stakes and linking the regional and national levels, Nunca Máis reached a much wider audience while reducing transactional costs. The emergence of the movement must also be explained by the sheer magnitude of the ecological disaster and its devastating impact on the economy of the region. 
From all the elements conducive to the emergence and continuing activity of Nunca Máis - such as a favourably-perceived non-political circumstance, the previous existence of social networks, the enlargement of the initial agenda, the merging of the regional and national contexts, and the scale of the environmental catastrophe - the only factors that belong to the concept of political structure are decentralization (a structural dimension) and the existence of political allies (a situational dimension).

\section{THE CONSEQUENCES OF NUNCA MÁIS: FRAMING PROBLEMS} AND THE LACK OF A SHARED IDENTITY

The success of the early Nunca Máis demonstrations, together with the massive anti-war protests, appeared to indicate that the Prestige disaster offered an opportunity for political change at the regional level, and even at the national one. However, the local and regional elections held in May 2003 disappointed these expectations as the main opposition party, the PSOE, did not capitalize significantly on the social discontent. Leaving aside the analysis of electoral results at the aggregate level, the surprisingly strong support for the PP in Galicia has to be explained in terms of the uneasy coexistence of the two principal types of (potentially conflictive) participant in Nunca Máis:

(1) a majority of compensation-seekers, mainly the fishing community, with a predominantly short-run interest;

(2) a minority of political benefit-seekers, adversaries of the PP, with a medium and long-run interest.

The second type of Nunca Máis member was basically represented by the left-wing and nationalist parties, as well as by the unions, whose interests did not really require an ongoing consciousness-raising campaign as they were simply seeking an opportunity to increase their political leverage. By contrast, the first type of participant included PP voters and sympathizers. In order to maintain their support for the movement, these people required a more sustained campaign on the part of Nunca Máis so that their short-term economic interests - focused on compensation payments as a result of the prohibition on fishing decreed by the Xunta - could be placed within a broader framework. Issues of framing and collective identity were very relevant in this case, above all once compensation payments began to reach those affected by the spillage and the initial reactions of anger and concerted action started to decline. In effect, the protest seemed to unite these two groups, but their 
'hidden and private' interests were markedly different, so that, once the peak of the mobilization cycle was passed, problems arose as to how to define and sustain a single collective identity. Beyond the division between compensation and political-benefit seekers, the policy of indemnities adopted by the Xunta and the central government helped create an important divide within the movement.

\section{Policies of Compensation and Electoral Failure}

The Xunta's prohibition on fishing activities was initially offset through economic compensation for those affected. The process of compensation was rapidly executed by means of a series of regional orders (up to 19 were published in the DOGA, the official bulletin of the Xunta). These gradually increased not only the amount of money to be paid, but also the time during which it would be paid. Further, the orders also increased the number of collectivities entitled to receive the aid, these being extended from fishermen to local traders and ship owners. The very first order, dated 18 November 2002 and envisaging a payment of 30 euros per fisherman per day for a month, was soon followed by royal decree $7 / 2002$, issued by the Ministry of Agriculture and Fishing on 5 December 2002, which added that another 10 euros per day would be received by each fisherman.

Once fishing activities resumed, the compensation payments were withdrawn, though the timing depended on the sector and the sea area in question. Although fishing began again in March 2003, it was not until October 2003 that all sectors were active. It should be noted that the compensation procedure adopted by the Xunta was entirely new. In the case of the Mar Egeo accident of 1992, for example, compensation was paid exclusively by the FIDAC (International Fund for the Compensation of Oil Pollution Damages) and was received a full ten years after the spillage.

Many people were grateful for the swiftness and the 'generosity' of the compensation payments. One might add that numerous individuals were also employed by the TRAGSA company to clean up the beaches, thereby increasing their income by over 1,200 euros a month (and leaving them better off than if the disaster had not occurred). In consequence, these social sectors adopted a short-term perspective that clashed directly with the medium and long-term concerns of the other sectors affected. The latter stressed that they were entitled to receive compensation above and beyond the economic losses because of the political mismanagement in relation to the disaster. This, they argued, was reflected in the decision to deny the Prestige shelter in a harbour, the choice of the worst route 


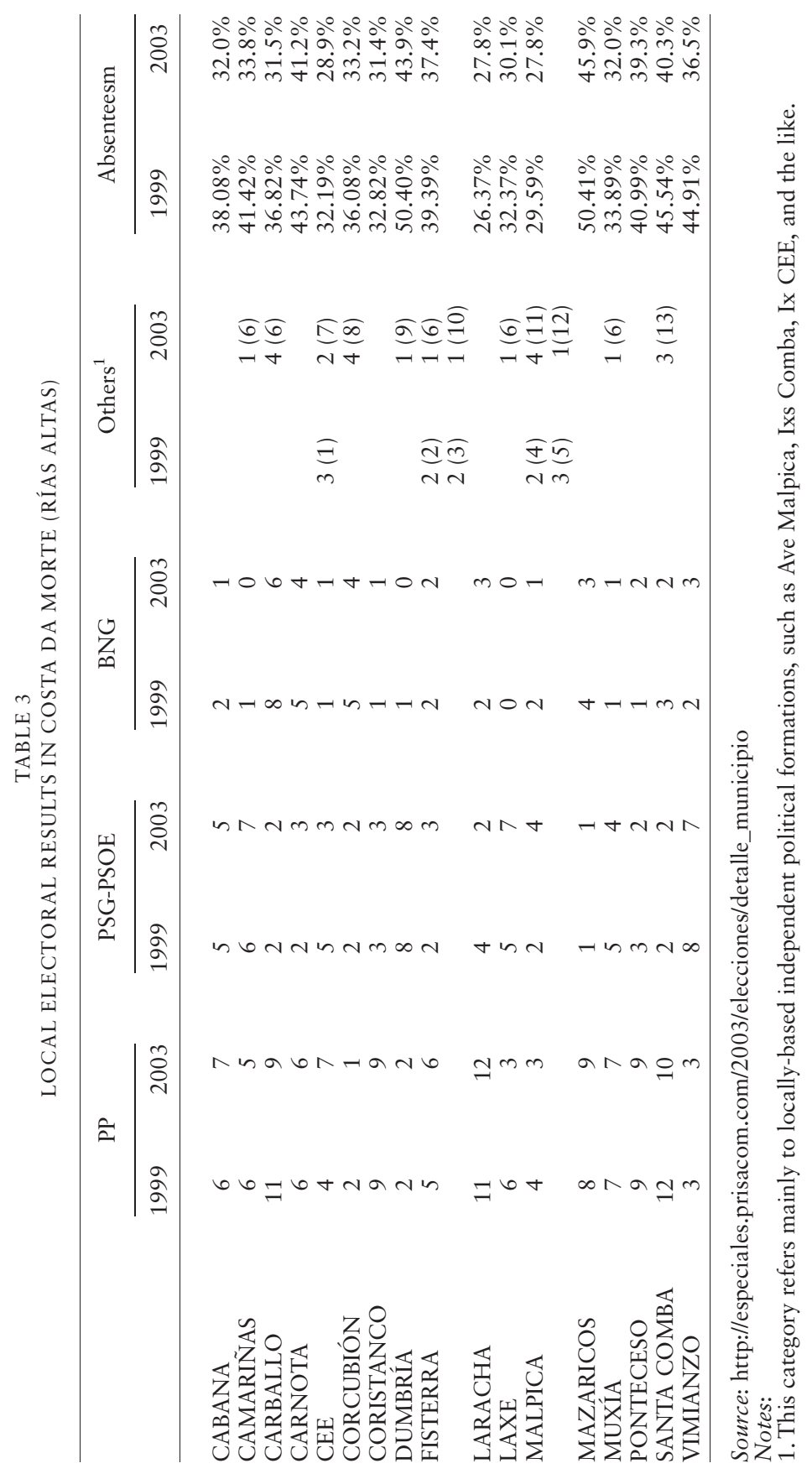


possible to distance the tanker from the coast, and, finally, the refusal initially to 'attack' the spillage in a pro-active fashion.

These differing ways of framing the compensation payments, involving a clash between 'generous aid' and 'undeniable entitlement', goes a long way to explaining the different voting patterns in the Galician local elections. Noteworthy in this respect is the political cleavage between the more conservative Rías Altas (for instance, around 80 per cent of the cofradias around La Coruña are sympathetic to the PP), and the nationalistic inclination of the Rías Bajas.

If we confine ourselves to analyzing the municipal election results in the area most damaged by the spill, the Costa da Morte in the Rías Altas, the PP certainly lost councillors in comparison with the previous elections of 1999. But the loss was not as dramatic as expected: indeed, only three councillors were lost in total. However, the instigator of Nunca Máis, the BNG, was the worst hit of all the parties, losing seven councillors, while the representation of the PSG-PSOE remained unchanged. Finally, the independent lists seem to have benefited most of all from the ecological disaster, having gained 12 councillors.

Two principal reasons as to why the local elections were not more damaging to the PP, beyond the traditional political cleavage between the Rías Altas and the Rías Bajas, were the divisions within the fishing community and the absence of a favourable political opportunity structure. A further divisive element within the fishing community is the fact that the interests affected by the spillage have to choose between two different, and mutually exclusive, compensation packages. The choices are:

(1) To resort directly to the FIDAC by suing the shipowner, the insurance company, and so on. This entails a long process whose most optimistic outcome would be the granting of 171 million euros, though this money would have to be distributed amongst all the countries affected. Those affected can also turn to the courts in order not only to claim compensation for future losses if the ecological damage is greater in the medium term than initially expected, but also to demand political responsibilities.

(2) In accordance with the strong recommendation of the public authorities, to endorse the royal decree 4/2003, dated 20 June 2003, which envisages compensation of 160 million euros (60 of them having already been granted by the FIDAC to the Spanish government, while the origin of the other 100 million is not yet clear) to be distributed by the Official Credit Institute (ICO) on the condition that future judicial or economic claims are renounced. 
As the decree makes clear, this mechanism 'does not entail, in any case, acknowledgement of any state responsibility for the effects [of the spillage] and is adopted without prejudicing the state's rights to claim from those responsible the indemnities that are deemed appropriate'.

The problematic nature of the last option lies in the fact that although compensations were allegedly for life annuity, it now appears that the government aims to get its money back via the FIDAC. In effect, the eventual aid to be received by those who have accepted the terms of the royal decree will be less than expected because the government will subtract the sums already given to those affected. Moreover, nobody can assure those affected that the money received as a result of the royal decree will cover more than probable future losses. The Spanish Maritime Institute, for example, has stated that the seabed is still seriously polluted, that fish hauls have decreased between 25 per cent and 50 per cent, and that the spillage will affect the maritime food chain in both the medium and the long term. At the same time, the government has deprived those affected of an important political weapon: the possibility of sueing politicians and others involved in the management of the disaster of the Prestige for their mistakes.

The fishing community is divided over the governmental strategy of granting rapid compensation payments as long as legal claims are renounced. While 15,000 fishermen have accepted the government's proposal, around 12,000, embracing Basques as well as Galicians, have rejected it and set up a Coordinating Committee of Fishermen's Associations (Coordinadora de Cofradias). For most fishermen, as a result, economic aid has prevailed over political denunciation. ${ }^{8}$ The government has also endeavoured to appease those regional interests that were still sceptical through further economic measures. In January 2003, Prime Minister José María Aznar unveiled the so-called Galician Plan, according to which the region will receive another 12,000 million euros in investment.

\section{CONCLUSIONS: THE FUTURE OF NUNCA MÁIS AS A JIMINY CRICKET'S VOICE OF CONSCIOUS}

The well-known definition of a social movement as a 'collective interaction among makers of claims and their objects when at least one government is a claimant, an object of claims, or a party to the claims and the claims, if realized, affect the interests of at least one of the claimants' (McAdam, Tarrow and Tilly, 2002: 5), helps us understand why Nunca Máis, 
which was composed of different 'claim-makers' who eventually fell out, has had a far more negligible political impact than expected. Had those affected stuck by their original demands, the situation of the PP at both the regional and national levels would probably have been very different. There would, in all likelihood, have been a Cabinet reshuffle at the regional level, and, later, at the national one, while the economic costs of regenerating the coastal area and implementing a reliable maritime policy would have soared.

In reality, most of the initial demands were abandoned while the government's strategy to undermine Nunca Máis by means of an uneven distribution of compensation payments proved reasonably effective. Furthermore, the fact that political perceptions and realities clearly diverged in the case of Nunca Máis does much to explain why the movement failed to bring about significant political change in Galician and national politics.

The stress on the opening up of political opportunities, as the main independent variable of the political process approach for the emergence of social movements, clearly does not account for the emergence of Nunca Máis. This is not only because the opening, having been imagined by the movement, never really existed. It was also because the challengers lost sight of the time perspective: the attempt to transform the initial window of opportunity (the collective ire and indignation unleashed by the magnitude of the spillage) into a longer-term horizon of opportunity (through enlargement of the boundaries of the protest and the movement's political agenda) did not prosper in the end. The emergence of the social movement of Nunca Máis is better explained by the generalized shock produced by the sheer scale of the environmental and economic damage and by the previous existence of social networks that were quickly and effectively mobilized by the political opposition to the PP.

If we follow Gamson and Kitschelt's distinction (in Kriesi, 1992: 122) between 'procedural' success, which entails the creation of new channels of participation for the challengers once they are acknowledged as legitimate representatives, and 'substantive' success, which involves policy and legal changes as a result of the protest, Nunca Máis' achievements were rather limited. As regards the former, the social movement encountered a responsive audience amongst substantial sectors of public opinion as well as amongst the opposition parties, but it was never called upon as a negotiating partner by the PP administrations. Indeed, the Galician and national governments launched a concerted attack on the image of Nunca Máis, including casting doubts on its financing.

As far as 'substantive' success is concerned, nobody from within the political realm resigned or was ousted from power, while important 
promises, such as the commitment to buy an anti-pollution ship, the building of a shelter-harbour, and the putting into practice of the Pescanova project, have not been fulfilled. Therefore, following DeGroot's analysis (1998: 9) of students' protests, it might be 'better to speak of the legacy, rather than of the achievements' of Nunca Máis.

Nunca Máis is now a social movement with a stable organizational structure which gathers regularly in order to analyse the aftermath of the disaster of the Prestige as well as to engage in critical debate about current politics. Suso de Toro, the winner of the 2003 National Prize for the best novel and one of the leaders of the movement, has recently affirmed that Nunca Máis was the first time a new, public space had been created in Galicia since the age of the Catholic Kings. The existence of this space, in which people first gathered to protest at the Prestige spillage and which now contributes to debate about different aspects of regional and national government, has undoubtedly transformed Galician society.

Despite its limited political success, Nunca Máis has functioned, and still does, as a sort of Jiminy Cricket voice of conscious. Suso de Toro has also proclaimed that 'Nunca Máis expresses a sustained anger and a new dignity'. At the last demonstration organized by Nunca Máis, in Santiago on 16 November 2003 in remembrance of the spillage's first anniversary, the slogan chosen was ' 365 days of dignity and incompetence'. ${ }^{9}$ Further, Manuel Rivas, another high-profile writer from the movement's leadership, having read the so-called 'Manifesto of the Nine Waves', referred to the waves of dignity, memory, truth, solidarity, freedom and hope, amongst others, and brought the event to a climax with a toast 'to the sea and to dignity'.

\section{NOTES}

1. The PP national and regional government vigorously attempted to portray Nunca Máis as a gang of radicals who were bent on polarizing Galician society. See La Voz de Galicia (14 Feb. 2003, 19 Feb. 2003, 21 Feb. 2003).

2. Manuel Fraga Iribarne, Minister of Information and Tourism from 1962 to 1969 under the Franco regime, was considered too liberal for the dictatorship, but too right wing for the Transition of 1976-78. In 1976 Fraga founded the Alianza Popular (AP) party, which failed miserably in the general elections of 1977 and 1979, especially in comparison with the victorious centre-right formation of the Unión de Centro Democrático (UCD) under Adolfo Suárez. During the Transition and the 1980s, Fraga was perceived by many Spaniards as being too old-fashioned and authoritarian a politician for the new, democratic Spain, yet this did not prevent him from becoming President of the regional Galician government, or Xunta, in 1989. Alianza Popular was renamed 'el Partido Popular' (PP) in 1989.

3. As president of the Galician PP and of the Xunta, Fraga undertook a process of 'Galicianization' of the party. This was 'based on the establishment of firm bases for the party apparatus, the consolidation of provincial and local networks of clientelism by 
means of exchange mechanisms between the Xunta and the citizenship, and the appropriation of Galician cultural elements (embracing ideological and symbolic elements from Galician tradition) from a regionalist perspective, all of which have put him in touch with the diffuse, deferential feelings of the electorate as well as exploit a regional dialectic of opposition to a Socialist government at the state level until 1996' (Máiz, 1996).

4. The only polemical political issue at the time, if any, was the Law of Universities (LOU), approved by the PP at the state level. The application of the new law mobilized teachers and students for over three months, but the protest, supported by Galiza Nova (a BNG affiliated youth-association), was largely confined to the University of Santiago.

5. This structural dimension draws on Kitschelt's distinction between 'political input structures' (the degree of openness in terms of the way in which access to the polity is conditioned by territorial centralization, the state's functional concentration, public administration coherence and the institutionalization of direct democratic procedures) and 'political output structures' (the degree to which the state can implement and enforce policies) (in Kriesi, 1992: 120).

6. This structural dimension overlaps with the fifth situational dimension, that is, the decline in the state's capacity to exert repression. Kriesi (1992) also makes a distinction between the stable properties of the political context - which embrace the formal and institutional structures of the state, the informal procedures and prevailing strategies of the members of the polity in relation to the challengers, and the structure of power within the parties and trade unions - and the less stable ones (or the context of interaction), which can be derived from the former properties: the strategies of the authorities and the challengers, which are mutually interdependent, the mix of facilitation and repression, and the balance between the probability of the success of the social movement and the probability of reform undertaken by the authorities, even in the absence of collective action.

7. The post-POS would refer to 'the state's mode of repression and social control' (the third structural dimension of the concept), which the challengers have to deal with once they have initiated their collective action.

8. This was bluntly put by Lucas Toba, president of the goose barnacle industry in Muxia: 'In my role as president, I have to protect a hundred families, so if I have to shut up, I will' (Interviú, 1437, 2003: 43-4).

9. Susa de Toro, in Interviú, 1437, 2000: 46.

\section{REFERENCES}

Alongside the webpages indicated, we have also made extensive use of the following newspapers and magazines: El País, El Mundo, La Voz de Galicia, El Correo Gallego, and Interviú.

Aguilar, S., N.Y. Font and J. Subirats (eds.) (1999): Política ambiental en España. Subsidiariedad y desarrollo sostenible, Valencia: Tirant Lo Blanch.

Alcántara, M. and A. Martínez (eds.) (1998): Las elecciones autonómicas en España 1980-1997, Madrid: CIS.

Baker, S., M. Kousis, D. Richardson and S. Young (eds.) (1997): The Politics of Sustainable Development, London: Routledge.

Bleiker, R. (2000): Popular Dissent, Human Agency and Global Politics, Cambridge: Cambridge University Press.

Cabrera, J. (1994): 'Las precondiciones sociales de la identidad colectiva de Galicia', in Historia y Crítica, No. 4, 209-39.

DeGroot, G.J. (1998): Student Protest, New York: Addison Wesley Longman.

Della Porta, D. and H. Rieter (eds.) (1997): Policing Protest: The Control of Mass Demonstrations in Contemporary Democracies, Minneapolis: University of Minnesota Press. 
Goodwin, J. and J.M. Jasper (eds.) (2003): The Social Movements Reader, Malden: Blackwell.

Kriesi, H. (1992): 'El contexto político de los nuevos movimientos sociales en Europa Occidental', in J. Benedicto and F. Reinares (eds.), Las transformaciones de lo político, Madrid: Alianza Universidad.

Loveman, M. (1998): 'High-Risk Collective Action: Defending Human Rights in Chile, Uruguay and Argentina', American Journal of Sociology 104/2, pp.477-525.

Máiz, R. (1996): 'Nación de Breogán: oportunidades políticas y estrategias enmarcadoras en el movimiento nacionalista gallego (1886-1996)', Revista de Estudios Políticos No.92, 33-78.

Maíz, R. and A. Losada (2000): 'Galicia: autogobierno y desarrollo en una comunidad autónoma española', Memoria, No.142, diciembre.

Maíz, R. (2000): 'Dimensións da identidade colectiva de Galicia' (http://www.cirp.es/prx/ proxectos.html).

McAdam and D.A. Snow (eds.) (1997): Social Movements, Readings on their Emergence, Mobilization and Dynamics, Los Angeles: Roxbury.

McAdam, D., S. Tarrow and C. Tilly (2002): Dynamics of Contention, Cambridge: Cambridge University Press.

Núñez, X. (1997): 'National reawakening within a changing society: the Galician movement in Spain (1960-97)', in Nationalism and Ethnic Politics, 3/2, pp.29-56.

Paniagua Soto, J.L. (ed.) (2000): Gobierno y administración en las Comunidades Autónomas, Madrid: Tecnos.

Tarrow, S. (1998): Power in Movement, Cambridge and New York: Cambridge University Press.

Tilly, C. (1978): From Mobilization to Revolution, Reading, Mass. Addison-Wesley.

Vilas Nogueira, J. (1992): 'Las elecciones en Galicia (1976-91)', Santiago: Universidad de Santiago de Compostela, working paper, No.57.

Zirakzadeh, C.E. (1998): Social Movements in Politics: A Comparative Study, London and New York: Longman. 